\title{
Discussion on the Reform of Professional-ability-oriented Accounting Undergraduate Education
}

\author{
Lingyan $\mathrm{Ou}^{1,2, \mathrm{a}}$, Yan $\mathrm{Pan}^{1,3, \mathrm{~b}}$ \\ ${ }^{1}$ Financial and Accounting Research Center,Social science research base of Fujian Province, \\ Fuzhou 350000, China \\ ${ }^{2}$ Department of Accounting, Fujian Jiangxia University, Fuzhou 350000, China \\ ${ }^{3}$ School of economics and management, Fuzhou University, Fuzhou 350000, China \\ a22087335@qq.com, bfzdxpy@163.com
}

Keywords: Accounting, Undergraduate Education, Professional Ability, Reform.

\begin{abstract}
Accounting undergraduate education is an important issue in the field of accounting professional education. We take the undergraduate accounting education model as the research object, combined with normative research and investigation, then analyzes the practical needs of accounting professional ability, and puts forward ten kinds of accounting professional competence elements. Based on the analysis of the present situation and existing problems, we give the suggestion and measurements to promote the accounting education reform, in order to improve the quality of accounting undergraduate education in China.
\end{abstract}

\section{Introduction}

Nowadays, in the age of electronic commerce comes, accounting is becoming more and more important. Cause the continuous development of economic and social change,financial instruments emerge in an endless stream of innovation evolution, the market competition is increasingly fierce... all of these phenomenon make the demand for accounting talents is increasing, and a higher standard is put forward for the requirement of accounting personnel ability. When the reality of accounting personnel training is not consistent with the expectations of the society, it is necessary to reform the personnel training mode. So it is urgent to explore new teaching reform mode with "ability and application" as its core, and to cultivate "compound, innovative and applied" accounting talents.

In view of this, the paper discusses the reform of accounting undergraduate education, which is driven by professional ability. Through the analysis of the current status of accounting undergraduate education, we reveal the existing problems, analyze the stakeholders' demand for accounting professional competence.Then the paper puts forward the path of accounting education reform driven by professional ability and corresponding countermeasures, aims to make contribution to the accounting education reform in China.

\section{Current situation of accounting undergraduate education in China}

\subsection{An overview of the current situation of accounting education}

From the realistic perspective, the current undergraduate accounting education lags behind the accounting reality. It leads to the gap between the demand and the reality of accounting ability , in particular, the students' general ability training is insufficient. For the training of professional skills, accounting curriculum emphasizes the rules of accounting, ignoring the professional judgment and the consequences of decision making. The innovative accounting teaching methods are relatively inadequate. Objectively speaking, although now it has made great progress in quantity and quality, the accounting education in China can not meet the needs of economic development for the accounting personnel ability. The irrelevance of the undergraduate accounting education, accounting practice and accounting research, further exacerbates the bipolar tendencies of supply of accounting curriculum and the rigidity of teaching method. In addition, China's current accounting 
undergraduate system is not reasonable, for example, the content of some specialized courses are repeated, the proportion of professional courses and public basic courses is not reasonable, information application is insufficient, etc.

\subsection{The requirement of accounting professional ability}

Through the stakeholders of accounting education (accounting personnel, accounting teachers and students), we analyzes the views on accounting undergraduate education, summarizes the reform of accounting undergraduate education requirements.

\subsubsection{Questionnaire design and sample selection}

According to the different stakeholders, we designed 3 versions of the questionnaire versions. Each questionnaire is divided into 2 parts. The first part is the ability and quality of accounting graduates.

The second part is an overview of teaching methods.Specifically include:

(1) the needs of different stakeholders on the ability of accounting professionals?

(2) the views of different stakeholders on the current accounting teaching methods?

The questionnaire was released in January 1, 2016 and the deadline was June 30 by direct interview and e-mail questionnaire.A total of 800 questionnaires were distributed, and a total of 712 questionnaires were collected, the valid questionnaires were 685 .

In 685 valid questionnaires, the accounting personnel is 135 , accounting for $19.71 \%$ of the total sample; the university teachers is 124 , accounting for $18.10 \%$; the total number of students was 426 , accounting for $62.19 \%$ of the total sample. There are some differences in the distribution of different types of samples, which may have an impact on the analysis of the data.

\subsubsection{Analysis result}

Through the existing research results and interviews, we obtained the 10 accounting occupation ability value, respectively: (1)Accounting handle ability; (2)Software operational capability; (3)information gathering ability; (4)Professional judgment; (5)team work; (6)Decision analysis ability; (7)Expression ability; (8)Acquire new knowledge ability; (9)Innovation ability; (10)Software design and maintenance.

The results also show that the mode of accounting education in colleges and universities is closed and lack of actual demand. It can not meet the requirements of the development to emphasize the theoretical teaching, neglect the practice education and neglect the cultivation of professional ethics. The cultivation of comprehensive ability is emphasized.Faced with the impact of information technology, accounting education needs to adjust the plan to meet the changing needs of professional ability.Therefore, the accounting professional training mode must be judged by the demand of accounting personnel market.

\section{Analysis on the problems of undergraduate accounting education in China}

\subsection{New requirements on accounting professional ability in information environment}

As a part of the enterprise management information system, the accounting information system is more and more closely related with other departments. In addition to accounting capabilities, accounting talents also need to have the good non-accounting capabilities. The development of information technology has put forward higher requirements for the quality of accounting personnel, such as the professional judgment of decision-making ability, analysis ability, team cooperation ability, obtaining new knowledge ability and good communication skills...etc. But the current accounting education in China still focus on the development of accounting ability, the training of accounting professional students' non-accounting ability is relatively insufficient. The current teaching goal is still too much emphasis on accounting information accounting recognize, measurement, record and reporting, is relatively insufficient on the non-technical-ability training. It is resulting in the poor practical ability, and the students do not know how to use these generated information to help solving the increasingly complex management problems.

\subsection{Lack of support for experiment teaching}

First of all, the existing experiment course has the following problems, such as: lack of experiment class, lack of experiment conditions, the experiment content is artificially fragmented, and so on. 
Secondly, the lack of information technology courses. The college usually open accounting software application course, which mainly teaches the process of accounting activity by using computer financial software. But other programs, such as management information system, enterprise management sand table simulation, computer audit, internal control courses offered in the undergraduate accounting professional are less.

Third, the practice teaching mode is lack of comprehensive training, accounting analysis and other management training, leading to accounting graduates can not adapt to the requirements of accounting information, and the teaching effect is not prominent.

\subsection{The effect of Innovative methods is not ideal}

At present, accounting teaching is still based on classroom teaching, which is a simple professional knowledge and business operation teaching. Although some new methods, such as case teaching, role modeling, autonomous teaching, teaching and innovative teaching methods can cultivate students' communicative competence and analysis ability, the results are not satisfactory. At the same time, the use of information technology in the accounting teaching is not frequently, can not give full play to the role of multimedia technology and equipment. Therefore, how to master the modern information technology and lifelong learning skills, which is one of the key points of teaching reform.

\subsection{The professional quality and ability of the accounting teacher needs to be improved}

The ability of accounting teachers is not equal to the title and academic qualifications, but the ability to combine theory with practice. On the one hand, some teachers have practical experience. They can not grasp the new development and the change of the economic environment of accounting, so their relatively old teaching content is difficult to attract the interest of students. On the other hand, some young teachers are theoretical, but lack of practical experience. The two situation should be improved.

\subsection{Teaching effect assessment method is simple}

There are some problems in the assessment of accounting teaching effect. At present, most schools take a closed book examination. Although some schools increased the experiment assessment requirements, the proportion of experiment assessment is very low, and even be diluted. It should be said that the necessary examination is an important means to improve the quality of learning, but the simple closed test can not truly reflect the students' learning ability and practical ability. Some students get high scores through temporary assault, it is difficult to truly reflect the degree of knowledge.

\section{The path design of the professional ability driven accounting education reform}

The reform of accounting education highlights the cultivation of professional ability and autonomous learning ability. Design path as shown in Figure 1 below.

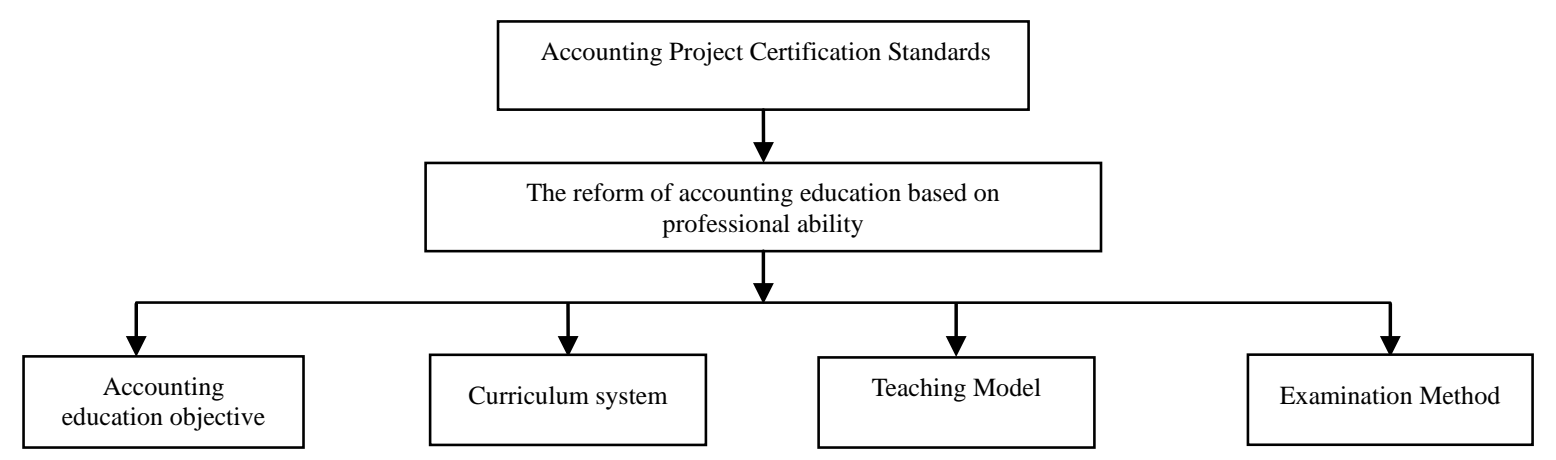

Fig. 1 The path design of the professional ability driven accounting education reform

As shown in Figure 1, the reform is a kind of institutional change, which is based on professional ability, actively invite practitioners to participate in the use of innovative learning teaching methods, and reflect the practice of teamwork. It also emphasizes that accounting education should continue to understand accounting practice, update teaching materials, and meet market demand. Obviously, 
promoting the continuous integration of accounting education, accounting academic research and accounting practice, has become the global trend of the future of accounting higher education.

The core of reform is the establishment of professional ability oriented personnel training system, and promote the continuous integration of accounting education, accounting academic research and accounting practice, for the future of the global trend of higher accounting education. And the content of reform is include four aspects, they are listed as below: the reform of accounting education objectives, curriculum reform, teaching mode reform and the reform of assessment methods.

\section{Countermeasures and suggestions}

China's higher education has completed thirty years of leapfrog development, and now needs to improve the education quality. At present, the state vigorously develop modern vocational education, focusing on the training of application-oriented and skilled personnel, the future of higher education will focus on ordinary undergraduate and technical personnel training. We can learn from the international experience of accounting education evaluation and quality certification, for example, the introduction of the United States AACSB accounting certification standards, develop different accounting personnel training policies according to different stages.

5.1 The improvement of accounting undergraduate teaching mode with Chinese characteristics First of all, different types of schools can form their own unique system of general education according to the characteristics and resources of personnel training. The setting mode of the specialized basic courses and core courses should be based on the level and characteristics of the students. Secondly, we should give up the unified standard of the textbook and the learning method of the standard answer, draw lessons from the foreign advanced accounting education methods, and use the micro teaching to make the students become the leading role in the class. Teachers play the role of "director" and "incubator", guide the students to do data collection outside the classroom preparation before class, organize the students to report case discussion and practice, let more students improve the judgment ability, communication ability and team cooperation ability etc.. Teachers can attract students to participate in their scientific research activities, promote the transformation of knowledge into ability in the process of cultivating students' independent thinking ability. Third, we can improve the evaluation index system of the school, pay attention to the evaluation of the students' ability, change the current situation of the final examination results, improve the mid-term examination proportion and learning effect. Fourth, education department can strengthen the cooperation with enterprises and other educational institutions, cultivate innovative high-quality personnel with practical ability ,then form the teaching mode of Chinese characteristics.

\subsection{Training high quality accounting reserve teaching talents}

One of the keys to improve the talent training mode is to cultivate high quality accounting teachers. At present, there is a lack of social platform to promote the balanced development of accounting teaching, practice and academic research. The state should set up some security mechanisms for the accounting teachers, introduce policies to guide practitioners to provide relevant academic research materials, promote the combination of accounting research and accounting practice, and encourage teachers to participate in practice. At the same time, the policies should be built in order to guide the convergence of accounting practice and teaching work, increase the efficiency of the use of scientific research and transformation, update accounting knowledge, support the relevant supporting system to help accounting teaching reform.

\subsection{The implementation of the "student-center" management model}

Due to the teacher-student ratio institutional barriers, domestic colleges and universities can not completely copy the American elite education model, but we can learn from the American model, such as: focus on the development of students' personality, the implementation of self management mode of "student-center". First of all, through the improvement of campus teaching system and the guidance of teachers, we can give students full transparency of information to achieve their own professional courses and teaching activities, then to achieve their self management ability. Secondly, 
providing the social practice opportunities, such as research assistants, a variety of professional entrepreneurship competition, in order to develop the overall quality and ability of students.

\subsection{Establishing the accounting professional market information database}

Establish an accounting database to collect, analyze and disseminate information about current and future job markets.We can learn from the experience of American accounting education, start the national accounting database, to reflect the accounting industry employment and development. These data will be combined with the higher education database to study and plan the future supply and competence of accounting practitioners. Using this method, we can effectively link the needs of accounting practice and the supply of accounting undergraduate education.

\section{Conclusions}

The continuous development of economic and social has demanded more accounting personnel, and higher standards are put forward for the professional ability and quality of accounting personnel. When the reality of accounting personnel training is not consistent with the expectations of the society, it is necessary to reform the accounting personnel training mode.

The paper analyzes the different needs of the stakeholders on the accounting professional ability, then put forward ten accounting professional ability factors. They are listed as below: accounting ability; software operational capability; professional judgment; team work; decision analysis ability; expression ability; acquire new knowledge ability; innovation ability; software design and maintenance ability.

Through analysis of the current situation and existing problems of accounting undergraduate education, we put forward the path of the reform of accounting education driven by professional ability. It takes the accounting project certification standards as guide, and takes the professional ability as the comprehensive goal, specifically consists of four parts: accounting education goal, accounting curriculum system, teaching mode, and examination method.

Finally, the paper puts forward suggestions to reform the accounting undergraduate education in China. The countermeasures are emphasized as : the improvement of accounting undergraduate teaching mode with Chinese characteristics; training high quality accounting reserve teaching talents; the implementation of the "student-center" management model; and establishing the accounting professional market information database.

\section{Acknowledgments}

This work is financially supported by National Soft Science Foundation of China (No. 2014GXS4D116), Fujian Social Science Fund (No.FJ2015JDZ048) and Fujian jiangxia University Scientific Research Personnel Training Fund(No.JXS2013008).

\section{References}

[1] B.Apostolou,J.W. Dorminey,J.M. Hassell. A summary and analysis of education research in accounting information systems (AIS), J. Journal of Accounting Education,8(2014):1-14.

[2] P.E.Madsen.Has the quality of accounting education declined, Accounting Review, 90(2015): :1115-1146.

[3] R.L. Humphrey, D.F. Beard. Faculty perceptions of online homework software in accounting education,J. Journal of Accounting Education,32,(2014): 238 - 258.

[4] Ching-Chi Lam,Loretta Un-Ieng Tou. Making Education Fun.The Marketing of Advanced Topics by Multimedia,J. Social and Behavioral Sciences,148,(2014):79 - 86.

[5] A.Nasseri, H.Yazdifar, D.Askarany. Management Accounting Education for the 21st Century Firms,J.International Journal of Finance and Managerial Accounting, 1,(2016):75-77. 
[6] R.E. Lilliea, D.E. Wygal. Virtual Office Hours in accounting coursework:Leveraging technology to enhance an integrative learning environment,J. Journal of Accounting Education,29 (2011):1 - 13.

[7] Abayadeera, Watty.Generic skills in accounting education in a developing country,J.Asian Review of Accounting, 24, (2016):149-170. 